\title{
GOOD FAITH IN INTERNATIONAL LAW
}

\author{
Steven Reinhold
}

\begin{abstract}
As a 'general principle', good faith forms part of the sources of international law. Still not widely examined in relation to rights and obligations, the aim here is to demonstrate the specific characteristics of the principle. In general, international law rules such as pacta sunt servanda, abuse of rights, estoppel and acquiescence and the negotiation of disputes are grounded, to some extent, in good faith. In treaty law, good faith has various manifestations from the time prior to signature through to interpretation. These are outlined here. The article argues that good faith acts to mediate the effects of States' rights in international law, in order to achieve acceptable results when competing interests exist. Fundamentally, good faith is a limitation of State sovereignty, albeit one that is necessary, as it protects other States and their trust and reliance in international law.
\end{abstract}

\section{A. InTROduCtion AND SCOPE OF THE TOPIC}

According to Art. 38 (1) (c) of the ICJ Statute, the Court "shall apply the general principles of law recognised by civilised nations". When treaties or customary law cannot yield a result, recourse is made to the general principles of law, ${ }^{1}$ of which good faith is perhaps the most important, as it underpins many international legal rules. ${ }^{2}$ The nature of good faith as an overarching legal principle makes it difficult to define in absolute terms. ${ }^{3}$ This brings to mind the (in)famous quote of Justice Stewart of the US Supreme Court, who stated: "I shall not today attempt to define [it]...But I know it when I see it." ${ }^{4}$ In this article the aim will not be to attempt an allencompassing definition of good faith, ${ }^{5}$ but rather to describe and exemplify its place in international law.

This article is in five parts. Firstly, it starts with an assessment of the

\footnotetext{
* Ph.D. candidate and Research Assistant to Professor Stefan Talmon, D.Phil., LL.M., M.A., Institute for Public International Law of the University of Bonn.

${ }^{1}$ Hersch Lauterpacht, International Law Vol. 1, (ed Elihu Lauterpacht, CUP 1970) 68; Malcolm N Shaw, International Law, (6 ${ }^{\text {th }}$ edn, CUP 2008) 98; James Crawford, Brownlie's Principles of Public International Law, ( $8^{\text {th }}$ edn, OUP 2012) 134.

${ }^{2}$ Nuclear Tests Case (Australia v France) (Merits) [1974] ICJ Rep 253; Shaw (n 1) 103; Michel Virally, 'Review Essay: Good Faith in Public International Law' (1983) 77 AJIL 130.

${ }^{3}$ William Tetley, 'Good Faith in Contract: Particularly in the Contracts of Arbitration and Chartering' (2004) 35 J Mar L \& Com 561, 563.

${ }^{4}$ Jacobellis $v$ State of Ohio 378 US 184, 197 (1964) (Supreme Court, per J Stewart), while actually referring to obscene material.

${ }^{5}$ Georg Schwarzenberger and Edward D Brown, A Manual of International Law, $\left(6^{\text {th }}\right.$ edn, Professional 1976). 118, 119, and Bin Cheng, General Principles of Law as applied by International Courts and Tribunals (Stevens 1953) 105, have also desisted; cf JF O'Connor, Good Faith in International Law (Aldershot 1991) 36.
} 
legal value of the principle of good faith in municipal legal systems, the means of transmuting this understanding of good faith into international law, and the differences and difficulties of this undertaking. Secondly, specific aspects of good faith are examined with particular reference to the jurisprudence of international courts and tribunals. Thirdly, the relation between the principle of good faith and sovereignty is assessed. The argument is that good faith acts as a means of limiting state sovereignty that is inherent in international law. Then, the impact of good faith is examined in the law of treaties, before the final conclusion.

\section{Good faith as a principle, a rule, or something altogether different?}

In his Hague Academy Lecture in 1957, Sir Gerald Fitzmaurice stated:

"By a principle, or general principle, as opposed to a rule, even a general rule, of law is meant chiefly something which is not itself a rule, but which underlies a rule, and explains or provides a reason for it. A rule answers the question 'what': a principle in effect answers the question 'why'.",

Ronald Dworkin distinguishes rules from principles by the fact that rules always apply in an unconditional, all-or-nothing way, whereas a principle will only act as a guide in a decision-making process. ${ }^{7}$ This distinction will provide a useful aid in determining the scope of good faith in its specific forms: while good faith can have an important role in the determination of obligations, it will generally not be the source of such obligations. This article argues that good faith serves a mediatory role between a rule and a principle.

\section{Good faith in municipal legal systems; recognition by "civilised nations"}

Even though the interests of States and individuals are very different with regard to the application of good faith, the jurisprudence of international law has borrowed the methodology of the municipal legal systems: the indefinability of the term 'good faith' has led to certain concretisations ${ }^{8}$ of

\footnotetext{
${ }^{6}$ Gerald Fitzmaurice, 'The General Principles of International Law considered from the Standpoint of the Rule of Law' (1957) 92 Recueil des Cours de l'Academie de Droit International 7.

${ }^{7}$ Ronald Dworkin, Taking Rights Seriously, (Harvard UP 1977) 25 f.

${ }^{8}$ The term is borrowed from Robert Kolb, 'Principles as Sources of International Law' (2006) 53 NILR 19 ff; a similar approach: Saul Litvinoff, 'Good Faith' (1997) 71 Tul L Rev 1997 1645, 1659 f, who calls the normative structures the 'critical areas'.
} 
the abstract notion of the principle. This is necessary, as good faith has limited practical application unless a court is in a position to examine and assess the conduct of the State concerned, and apply the principle accordingly. ${ }^{9}$ In order to identify common traits in three municipal legal systems, basic structures of this process can be identified in German, French, and English law.

In Germany good faith is most prominently codified in $\S 242$ of the Civil Code (Bürgerliches Gesetzbuch, hereafter 'BGB'), which states: "[ $\mathrm{t}] \mathrm{he}$ debtor has a duty to perform according to the requirements of good faith, taking customary practice into consideration." As a 'general clause' (Generalklausel), the judiciary and legal scholars have crafted and refined distinct legal precepts that can be applied to individual cases. ${ }^{10}$ Since a general clause is an open-ended legal provision, § 242 BGB requires balancing diverging interests in an individual case, in order to find the legal value of the provision and to make it applicable to a factual scenario. The direct application of good faith has therefore been limited to casuistry, i.e. an application of corrective justice tailored to the individual case. ${ }^{11}$ Some particular aspects that have developed are the prohibition of an abuse of rights (Rechtsmissbrauch), ${ }^{12}$ equitable estoppel (based on the principle of venire contra factum proprium), ${ }^{13}$ and acquiescence due to lapse of time (Verwirkung). ${ }^{14}$ The judiciary has had a prominent role in shaping the foundations of good faith: from a public law standpoint, the Lüth decision of the German Constitutional Court (Bundesverfassungsgericht ${ }^{15}$ paved the way for aspects of fundamental rights to be read into the general

\footnotetext{
${ }^{9}$ Cf Case of Certain Norwegian Loans (France v Norway) (Merits) [1957] ICJ Rep 9, para 54 (Sep Op Lauterpacht); Gerald Fitzmaurice, 'Hersch Lauterpacht: The Scholar as Judge: Part 1'(1961) 37 British Ybk Intl L 35.

${ }^{10}$ Dirk Looschelders and Dirk Olzen ' $\S 242$ BGB' in Julius von Staudinger, Kommentar zum Bürgerlichen Gesetzbuch Buch 2, (Sellier 2009) paras 211, 82.

${ }^{11}$ Looschelders and Olzen (n 10) para 102; Claudia Schubert and Günther H Roth ' $\S$ 242 BGB' in Franz Jürgen Säcker, Roland Rixecker and Hartmut Oetker (eds),

Münchener Kommentar zum Bürgerlichen Gesetzbuch ( $6^{\text {th }}$ edn, CH Beck 2012 ) para 14 f.

${ }^{12}$ BGHZ 30, 140, 140; Schubert and Roth (n 11) para 235; Looschelders and Olzen (n 10) para 214.

${ }^{13}$ BGHZ 50, 191, 196; Schubert and Roth (n 11) para 319; Looschelders and Olzen (n 10) para 286.

${ }^{14}$ BGHZ 105, 290, 298; Schubert and Roth (n 11) para 329; Looschelders and Olzen (n 10) para 302.

${ }^{15}$ BVerfGE 7, 198.
} 
clauses of law. ${ }^{16}$ It thus made $\S 242$ BGB receptive to an objective valuebased paradigm, ${ }^{17}$ which demonstrates the judicial activism in the application of good faith.

In France, good faith (bonne foi) is codified in Art. 1134(3) of the Civil Code (Code civil), which states that: "[Les conventions] doivent être exécutées de bonne foi". ${ }^{18}$ Even though bonne foi does not have the same elevated standing as in the BGB in Germany, the concept has recently acquired increasing importance. ${ }^{19}$ Indeed, French jurisprudence has developed alternative means of achieving similar results by resorting to other, related concepts, such as waiver and abus de roit $^{20}$ - concepts that fall under $\S 242$ in Germany. The reason why the 'general clause' idea has not been embraced can be explained by the fact that French law, similarly to English law, placed the creation of new cases of good faith into the hands of the legislature, rather than the judiciary. ${ }^{21}$

Turning now to English law, although Lord Mansfield stated in 1766 that good faith is "the governing principle... applicable to all contracts and dealings," 22 there is no general obligation to act in good faith. No single statutory provision or rule of English law clearly formulates the principle of good faith. Rather, the common law has developed what has been described as 'piecemeal solutions ${ }^{, 23}$ Instead of one overarching provision,

\footnotetext{
${ }^{16}$ Achim Seifert, 'Die Horizontale Wirkung von Grundrechten. Europarechtliche und rechtsvergleichende Überlegungen (2011) 14 Europäische Zeitschrift für Wirtschaftsrecht $696 \mathrm{f}$.

${ }^{17}$ Hans D Jarass, 'Die Grundrechte: Abwehrrechte und objektive Grundsatznormen. Objektive Grundrechtsgehalte' in Peter Badura and Horst Dreier (eds) Festschrift 50 Jahre BVerfG (Vol 2 Mohr Siebeck, 2001) 35 ff; Thomas Ritter, 'Neue Werteordnung für die Gesetzesauslegung durch den Lissabon-Vertrag (2010) Neue Juristische Wochenschrift 1110, 1114.

18 "[Agreements] must be performed in good faith" (own translation). Cf generally: François Terré, Philippe Simler and Yves Lequette, Droit Civil: Les obligations, $\left(9^{\text {th }}\right.$ edn, Dalloz 2005) para $439 \mathrm{f}$.

${ }^{19}$ Terré, Simler and Lequette (n 18) para 43 ff; Peter Jung, 'Die Generalklausel im deutschen und französischen Vertragsrecht' in Christian Baldus and Peter-Christian Müller-Graff (eds), Die Generalklausel im Vertragsrecht: Zur Leistungsfähigkeit der deutschen Wissenschaft aus romanischer Perspektive, (Sellier 2006) 37, 53; Reinhard Zimmermann/ Simon Whittaker, 'Good Faith in European contract law: surveying the legal landscape' in Reinhard Zimmermann and Simon Whittaker (eds), Good Faith in European Contract Law, (CUP 2000) 39.

${ }^{20}$ Looschelders and Olzen (n 10) para $1127 \mathrm{f}$.

${ }^{21}$ M Filippo Ranieri, 'Bonne foi et exercise de droit' (1998) 50 RIDC 1058.

${ }^{22}$ Carter v Boehm [1766] 97 ER (KB) 1162, cited by Tetley (n 3) 567; cf Patrick S Atiyah, The Rise and Fall of Freedom of Contract, (Clarendon Press, 1979) 168.

${ }^{23}$ Interfoto Pictures Ltd v Stiletto Visual Programmes [1989] QB 326, 439.
} 
there are several legal mechanisms that can deal with instances of perceived unfairness; these include misrepresentation and mistake, undue influence, estoppel ${ }^{24}$ and so on, as well as developments in equity. ${ }^{25}$

Lord Denning attempted (albeit obiter), in Lloyds Bank $v$ Bundy, the introduction of a general doctrine of unequal bargaining power. ${ }^{26}$ However, this approach was rejected by the House of Lords in National Westminster $v$ Morgan, where it was held that Denning's approach was neither justified, nor necessary, nor even desirable. ${ }^{27}$ The reasons for the reluctance of English courts to develop and apply a standard of good faith in contract law have been described as being threefold: firstly, the English courts adhere to the strongly individualistic nature of bargaining for one's own end, which necessitates the shunning of elements of social justice. ${ }^{28}$ Secondly, the courts have been reluctant to introduce a general principle of fairness. The competence to make such an encroachment into the law of contract is believed to lie with Parliament. ${ }^{29}$ The favoured piecemeal approach can be applied case-by-case, in order to select instances of manifest injuriousness and apply corrective means on an individual basis. ${ }^{30}$ Lastly, the elements of predictability and stability of the common law are seen as factors for the rejection of a general clause of good faith: as such a clause would be difficult to define, it would risk being too ambiguous to be enforced. ${ }^{31}$

\footnotetext{
${ }^{24}$ Stephen Smith, Contract Theory, (OUP 2004) $366 \mathrm{f}$ (misrepresentation and mistake), 348 (undue influence), 234 (estoppel); Guenter Treitel, The Law of Contract, (Edwin Peel ed, $12^{\text {th }}$ edn, Sweet $\&$ Maxwell 2007) 310 f (mistake), 361 (misrepresentation), 446 (undue influence), 146 (estoppel).

${ }^{25}$ For aspects of equity in international law, see Hugh Thirlway, 'The Law and Procedure of the International Court of Justice 1960- 1989: Part One (1989) 59 British Ybk Intl L 49 f; very instructive: Vaughan Lowe, 'The Role of Equity in International Law' (1988) 12 Aust Ybk Intl L 54.

${ }^{26}$ Lloyds Bank v Bundy [1974] QB 326, 339-340 (CA) (per L Denning MR).

${ }^{27}$ National Westminster Bank Plc v Morgan [1985] AC 686, 692, 707 (HL).

${ }^{28}$ Maud Piers, 'Good Faith in English Law - Could a Rule become a Principle?' (2011) 26 Tul Eur \& Civ L F 123, 130.

${ }^{29}$ Harbutts 'Plasticine' Ltd v Wayne Tank Pump Co Ltd [1970] 1 QB 447 (CA); Photo Production Ltd v Securicor Transport Ltd [1980] AC 827 (HL); Reinhard Zimmermann and Simon Whittaker, 'Coming to terms with good faith" in Zimmermann and Whittaker (n 19) 688, 690. Parliament did intervene with the Unfair Contract Terms Act 1977.

${ }^{30}$ Luigi Russi, 'Substance or mere Technique: A précis on Good Faith performance in England, France and Germany' (2009) 5 Hanse L Rev 21, 28.

${ }^{31} \mathrm{Cf}$ Walford $v$ Miles [1992] 2 AC 128, 138 (HL); Ewan McEndrick, 'The Meaning of Good Faith' in Mads Andenas, Silvia Diaz Alabart, Basil Markesinis, Hans Micklitz and Nello Pasquini (eds), Private Law Beyond National Systems Liber Amicorum Guido Alpha (BICL, 2007) 687, 691; Hugh Collins, Law of Contract, $\left(4^{\text {th }}\right.$ edn, CUP 2003) 181; Looschelders and Olzen (n 10) para 1149, 1150.
} 


\section{Importing municipal law into the Law of Nations "lock, stock and barrel"?}

When international courts and tribunals look to general principles of law, the private law institutions are not imported into international law 'lock, stock, and barrel'. ${ }^{32}$ Rather, in the words of Judge McNair, "the duty of international tribunals is to regard any features or terminology which are reminiscent of the rules and institutions of private law as an indication of policy and principles rather than as directly importing these rules and institutions." ${ }^{33}$ Accordingly, two levels have to be distinguished at which good faith has a legal value. Even though the principle of good faith has a well-defined municipal law counterpart, the international legal system has not imported these in its totality. Rather, a nuanced approach has been favoured.

The International Court of Justice (ICJ) has been reticent to turn directly to municipal law, in order to determine aspects of good faith. ${ }^{34}$ Yet, the general principles of municipal law require some mechanism in order to be 'elevated' into international law. ${ }^{35}$ Since an undifferentiated transmutation of municipal into international law is not applied, a different method has to be discerned. The method favoured by the Court seems to be a careful process of analogy. The municipal legal systems are examined in order to find a general legal rule that can be defined and stated in a 'pure form', which is achieved by making it widely applicable to the special interests that States have in their legal relations. By replacing the parties with algebraic forms, i.e. $x$ and $y$, which are then replaced with State A and State $\mathrm{B}$, the distilled rule is found and applied; if the general principle can still be applied in congruity with the aspects that are specific to international law,

\footnotetext{
${ }^{32}$ For a different phrasing of the question, cf RD Kierney, 'Sources of Law and the ICJ' in Leo Gross (ed), The Future of the International Court of Justice Vol. 2, (Oceana 1976) 701: "But wherein lies the magic of this philosophers stone that transmutes municipal into international law?".

${ }^{33}$ International Status of South-West Africa (Advisory Opinion) [1950] ICJ Rep 148 (Sep. Op. McNair); cf Hersch Lauterpacht, Private Law Sources and Analogies of International Law, (Longmans 1927) 83.

${ }^{34}$ Hermann Mosler, 'To What Extent Does the Variety of Legal Systems of the World influence the Application of General Principles of Law?' in TMC Asser Institute (eds) International Law and the Grotian Heritage (TMC Asser Instituut 1985) 180.

${ }^{35}$ Cf Hugh Thirlway, 'The Law and Procedure of the ICJ: Part Two' (1990) 62 British Ybk Intl L $114 \mathrm{f}$.
} 
then the general principle is applied in the given case. ${ }^{36}$

\section{Differences between national and international conceptions of good faith}

As municipal legal systems display different means of applying good faith, no single method can be identified. ${ }^{37}$ International law differs markedly from municipal law through its lack of comparable norm-creating and enforcement institutions. The system of international law is based on a voluntarist and co-operative character, best exemplified by the acceptance, for the most part, of customary international law; i.e. the law created and observed by the States themselves. ${ }^{38}$

There is, by and large, no central legislative body in international law. ${ }^{39}$ Without a central body to legislate in this area, an all-pervading obligation of good faith in international law is difficult to establish. ${ }^{40}$ The ICJ's case law is defined enough to act as a central source of guidance in applying the principle of good faith, but it is not competent to act as a law-generating institution. ${ }^{41}$ Indeed, it is questionable whether the international judiciary, made up of courts and tribunals, is best placed to serve an active role in the creation of good faith casuistry. The differing attitudes to the desirability of judicial activism in municipal legal systems would be greatly amplified in international law.

In municipal law, good faith acts to balance out unequal sides of a bargain. ${ }^{42}$ In international law this asymmetrical power balance, whether real or perceived, is absent. The principle of sovereign equality of nations dictates that there is no 'weak party' to a bargain in international law: by

\footnotetext{
${ }^{36}$ South-West Africa Cases (Liberia v South Africa) (Second Phase: Judgments) [1966] ICJ Rep 250, paras 296-297 (Diss Op Tanaka); Thirlway (n 35) 118. The methodology of the court is slightly controversial and cannot be fully examined here; for example Akehurst makes the point that it would be more efficacious only to apply the general principles that apply between the parties, rather than those of all civilised nations;

Michael Akehurst, 'Equity and General Principles of Law' (1976) 25 ICLQ 801, 824.

${ }^{37} \mathrm{Cf} \mathrm{O}^{\prime}$ Connor (n 5) 41.

${ }^{38}$ Cf Crawford (n 1) 16.

${ }^{39}$ Robert Jennings and Arthur Watts, Oppenheim's International Law Vol 1, $\left(9^{\text {th }}\right.$ edn, Longman 1992) 114; however, a trend is emerging whereby the UN Security Council is seen to be acting legislatively, cf Stefan Talmon, 'The Security Council as World Legislature' (2005) 99 AJIL 175.

${ }^{40}$ See generally Yuval Shany, 'Towards a General Margin of Appreciation Doctrine in International Law?'(2005) 16 EJIL 907, $920 \mathrm{f}$.

${ }^{41}$ Cf Thirlway (n 25) 58 (on the ICJ's reluctance to be seen as "legislating").

${ }^{42}$ Looschelders and Olzen (n 10) para 147; Klaus Adomeit, 'Die gestörte

Vertragsparität- Ein Trugbild‘ (1994) 38 Neue Juristische Wochenschrift 2467, 2468.
} 
"entering the Family of Nations a State comes as an equal to equals". ${ }^{43}$ This does not necessarily mean that States are completely equal as regards power, territory, and the like. But as States, they are legally equal, at least in principle, whatever differences between them may otherwise exist. ${ }^{44}$ As a result, even though sovereign equality can still serve to protect weaker States from the hegemony of stronger States, ${ }^{45}$ the fundamental conception of good faith as a means of corrective justice is not directly applicable to the relations between States.

\section{B. Specific Aspects of Good Faith in International LaW}

Like municipal law, good faith in international law has been subject to concretisations. In order for the international legal order to be predictable and consistent, scholars have examined and clarified the doctrinal aspects of these concretisations, while judicial bodies have applied them to factual scenarios. Though far from conclusive, four main concretisations are examined here, namely the maxim pacta sunt servanda, abuse of rights and discretion, estoppel and acquiescence, and negotiations in good faith. These have been subject to important judicial decisions and are recognised as sources of international law.

\section{Pacta sunt servanda}

The maxim 'pacta sunt servanda' has been said to relate solely to the law of treaties. ${ }^{46}$ However, based on good faith, the ICJ has found that that a State can be bound by a unilateral act alone: a public statement made by a State, with an intention to be bound, can create legal obligations, which could otherwise only be created through a treaty.

The rationale behind the maxim is seemingly self-evident: a need by the international community for a system that can ensure international order

\footnotetext{
${ }^{43}$ Hersch Lauterpacht, Oppenheim's International Law, ( $8^{\text {th }}$ edn, Longmans 1955) 263; Crawford (n 1) 449.

${ }^{44}$ Jennings and Watts (n 39) 339; this is described as the 'orthodoxy' by Gerry Simpson, Great Powers and Outlaw States, (CUP 2004) 26 f.

${ }^{45}$ Juliane Kokott, 'States, Sovereign Equality' in Max Planck Encyclopaedia of Public International Law (MPEPIL) (April 2011, online edn), para 43 ff, available at www.mpepil.com.

${ }^{46}$ Anthony Aust, 'Pacta sunt Servanda' in MPEPIL (February 2007, online edn) para 2, available at www.mpepil.com; Richard Hyland, 'Pacta Sunt Servanda: A Meditation' (1993) $34 \mathrm{Va} \mathrm{J}$ Intl L 405, 406. The maxim translates as "binding agreements must be kept".
} 
and prevent arbitrary behaviour and chaos. ${ }^{47}$ In the Nuclear Tests Case, the ICJ held that:

"One of the basic principles governing the creation and performance of legal obligations... is good faith. Trust and confidence are inherent in international cooperation, in particular in an age when this cooperation in many fields is becoming increasingly essential. Just as the very rule of pacta sunt servanda in the law of treaties is based on good faith, so also is the binding character of an international obligation. Thus interested States may take cognisance of unilateral declarations and place confidence in them, and are entitled to require that the obligation thus created be respected." ${ }^{48}$

The French Government declared that no more nuclear tests would be conducted in the Pacific. In this case the Court gave these statements by a State (the declaring State) the same legal effects that can usually only be attributed to a binding synallagmatic treaty towards the receiving State. The Court found that if some prerequisites were met, then a unilateral declaration can bind a State; these are: the context of the statement, the intention of the declaring State, no necessary acceptance by the receiving State or observance of formal requirements. ${ }^{49}$ For present purposes, the context and intent are most important.

The statement's context is important: it must be made publicly; a receiving State must be able to take cognisance of the declaration. The most important aspect of the binding nature is the (subjective) intention of the declaring State, as this distinguishes the statement from other, nonbinding statements. However, the (objective) trust and confidence that is placed in the statement by the receiving State is paramount to the creation of an obligation; here good faith acts as the norm regulating the legal effect of the act. ${ }^{50}$ The Court's reasoning shows that good faith can be a basis for

\footnotetext{
${ }^{47}$ Igor Ivanovich Lukashuk, 'The Principle Pacta Sunt Servanda and the Nature of Obligation under International Law’ (83) AJIL 1989513.

${ }^{48}$ Nuclear Tests Case (n 2) para 46 (emphasis added).

${ }^{49}$ The element of a form requirement is negligible, as international law imposes no strict requirements, therefore the statement may be made orally or in writing; cf Nuclear Tests Case (n 2) para 45. The fact that no formal acceptance is necessary seems to demarcate the unilateral statement from a formal agreement, Nuclear Tests Case (n 2) paras 43-50; cf Thirlway (n 25) 10-17; Camille Goodman, 'Acta Sunt Servanda? A Regime for Regulating the Unilateral Acts of States at International Law' (2006) 25 Aust Ybk Intl L 43, 53-59.

${ }^{50}$ Goodman (n 49) 57; Martti Koskenniemi, From Apology to Utopia, (CUP 1989) 308.
} 
legal obligations in the same way as the maxim pacta sunt servanda is for treaty obligations. ${ }^{51}$ However, some elements and the terminology of the case are contentious and there is no general rule to determine which unilateral acts give rise to legal rights and duties. ${ }^{52}$

\section{Abuse of rights and abuse of discretion}

Possibly the most contentious aspect of good faith in international law is the prohibition on the abuse of rights. The aspect of abuse of right and the arbitrary exercise of a right are closely related and not clearly distinguishable. An abuse of right is said to occur when a State exercises its rights in such a way as to encroach on the rights of another State, and that the exercise “... is unreasonable, and pursued in an arbitrary manner, without due consideration of the legitimate expectations of the other State." 53 The basis that prohibits this behaviour is good faith. If a State is able to exercise discretion, the arbitrary and unreasonable exercise of this discretion is said to amount to an abuse of rights, ${ }^{54}$ which a State can be held internationally responsible for. ${ }^{55}$ Abuse of rights may take place in three distinct sets of circumstances: ${ }^{56}$

(a) a State exercises its right in such a way as to hinder another State enjoying its own rights;

(b) a State exercises a right for an end which it was not intended for (improper purposes);

(c) arbitrary exercise of a right causing injury to another party.

As a result, the concept of abuse of right is often discussed in conjunction with the element of discretion that a State has in the exercise of

\footnotetext{
${ }_{51}^{51}$ Cf Vaughan Lowe, International Law, (OUP 2007) 74.

52 Jennings and Watts (n 39) 1190; The ILC has undertaken the task of examining the unilateral acts of state as a topic of appropriate for codification (cf ILC, 'Yearbook of the International Law Commission Vol II Part 2 (1996) A/CN.4/SER.A/1996/add.1 (Part 2) 141); Thirlway is critical of the Court's use of terminology here (cf Thirlway (n 25) 10). In his opinion the ICJ wanted to enunciate the principle to the effect that the giving of consent (consent to be bound) creates legal obligations. It is submitted, however, that, even if this were the case, the Court made itself clear in assigning trust and confidence a pronounced role in its judgment.

${ }^{53}$ Cf Lauterpacht (n 43) 345.

54 Tariq Hassan, 'Good Faith in Treaty Formation' (1980) 21 Va J Intl L 448; Gerald Fitzmaurice, 'The Law and Procedure of the International Court of Justice' (1953) 30 British Ybk Intl L 1, 53.

${ }^{55}$ Cf Trail Smelter Arbitration (United States of America v Canada) (1938/ 1941) III RIAA 1904, 1965; Cheng (n 5) 130.

${ }^{56}$ Alexandre Kiss, 'Abuse of Rights' in MPEPIL (December 2006, online edn) para $4 \mathrm{f}$, available at www.mpepil.com.
} 
its rights. ${ }^{57}$ Subsets (b) and (c) above borrow aspects from municipal administrative law, ${ }^{58}$ and there is some academic dispute as to whether they can be transmuted into international law. ${ }^{59}$ It is especially contentious whether international law has a comparable level of subordination ${ }^{60}$ between States. This would be a necessary prerequisite for the application of the ICJ's careful analogy of municipal administrative principles. ${ }^{61}$ For the careful analogous application of aspects of municipal law, based on the methodology of the ICJ, a level of subordination would need to be evident, i.e. a State would have to be in a position to be able to exercise rights over another State without prior consent.

The discretion left to States in the exercise of their rights is very wide. $^{62}$ In order to meet the threshold of an abuse of that right an element of bad faith is necessary. This is difficult to prove in front of a judicial body, ${ }^{63}$ as bad faith is never to be presumed but, rather, always has to be proven. ${ }^{64}$ As a whole, the Courts have not been forthcoming in holding States responsible for acts of abuse of right. However, two cases demonstrate how elements of abuse of rights can have an impact on the relations between States at the level of international law.

\section{i. Admission of a State to the UN}

In its Advisory Opinion on whether States were allowed to vote on the

\footnotetext{
${ }^{57}$ Michael Byers, 'Abuse of Rights: An Old Principle, A New Age' (2002) 47 McGill L J 389, 423; GDS Taylor, 'Content and Rule against Abuse of Rights in International Law' (1972) 46 British Ybk Intl L 323, 324 ff.

${ }^{58}$ For example: "détournement de pouvoir in France (see BO Iluyomade, 'Abuse of Right in International Law' (1975) 16 Harv Intl L J 47, 51), Willkürverbot in Germany (for the term cf Gerhard Leibholz, 'Ermessensmißbrauch im Völkerrecht' (1929) 1 ZäoRV 78 ff); see also Taylor (n 57) 336 f, 342 f for English administrative law.

${ }^{59}$ Cf part 0.

${ }^{60}$ Cf Rupert Klaus Neuhaus, Rechtsmißbrauchsverbot im heutigen Völkerrecht, (Duncker \& Humblot 1984) 86. Subordination is here meant to denote a vertical power balance of one State over another, as opposed to the horizontal balance dogmatically rooted in the sovereign equality of States.

${ }^{61}$ Cf Neuhaus (n 60) 88-90; Leibholz (n 58) 80-82.

${ }^{62}$ Cheng (n 5) 132; for a discussion of whether a general margin of appreciation is developing, see Shany (n 40) $931 \mathrm{f}$, who interprets the ICJ's jurisprudence as rejecting a margin of appreciation.

${ }^{63}$ Nevertheless, the abuse of rights has been advanced as a basis of claim in the Barcelona Traction Case, see Case concerning the Barcelona Traction, Light and Power Company, Limited (Belgium v Spain) (Judgment: Second Phase) [1970] ICJ Rep 17; cf Iluyomade (n 58) $70 \mathrm{f}$.

${ }^{64}$ Case concerning certain German Interests in Polish Upper Silesia (Germany v Poland) (Merits) [1926] PCIJ Rep 30; Virally (n 2) 132.
} 
admission of a new Member State to the UN, the Court was faced with Art. 4 (1) UN Charter. This provision laid out the prerequisites which a State must meet in order to be admitted to the UN. The question was whether the list of five conditions set out in Art. 4 (1) UN Charter were conclusive, or whether other (political) considerations could be taken into account. The conditions are that the candidate must be a State, which is peace-loving, accepts the obligations of the Charter, and is both able and willing to carry out these obligations. ${ }^{65}$

The Court concluded that no other conditions could be taken into account. ${ }^{66}$ The interesting aspect to note here is that the Court stated that, while discretion could be used by the voting State, it was curtailed by the limits set by Art. 4 (1) UN Charter. ${ }^{67}$ The dissenting judges agreed to the extent that the discretion was curtailed, but by the object and purpose of the UN Charter generally. For the evaluation of the relevance of good faith in determinations of this kind, it has to be noted that the judges all agreed that the discretion inherent in the right to vote must be guided by considerations of justice ${ }^{68}$ and must be "exercised in good faith", ${ }^{69}$ a duty that is also codified in Art. 2 (2) of the Charter.

\section{ii. Environmental cases}

Abuse of rights can also become particularly relevant when environmental resources are shared. ${ }^{70}$ Two cases highlight how an abuse of rights can arise between neighbouring States. The Trail Smelter Arbitration dealt with the fumes and air pollution produced by a Canadian smelter situated on the border of the US state of Washington. ${ }^{71}$ In the Pulp Mills Case, the ICJ had to decide a case brought by Argentina against Uruguay. Here a pulp mill had been built on the banks of the shared Uruguay River, which created

${ }^{65}$ Conditions of Admission of a State to Membership in the United Nations (Advisory Opinion) [1948] ICJ Rep 62.

${ }^{66}$ Ibid para 65.

${ }^{67}$ See also Taylor (n 57) 343.

${ }^{68}$ Conditions of Admission (n 65) para 71 (Diss Op Judge Alvarez).

${ }^{69}$ Ibid para 63.

${ }^{70} \mathrm{Cf}$ Kiss (n 56) para 4; this is based on the maxim sic utere tuo ut alienum non laedas or "use your property so as not to harm another"; Lauterpacht (n 43) 346.

${ }^{71}$ Trail Smelter Arbitration (n 55) 1905-1982; see Russell A Miller, 'Trail Smelter Arbitration' in MPEPIL (May 2007, online edn) para 2 f, available at www.mpepil.com; cf Lowe (n 51) 240. 
pollution and affected Argentina's use of the river. ${ }^{72}$ In both cases a State had built, or was planning to build, an industrial plant (the utilising State) that was going to cause some measure of environmental damage to neighbouring territory. Both developments were subject to international treaties outlining the obligations that the States had in relation to the undertaking.

The territorial sovereignty of a State allows for the exploitation of natural resources. However, this right is limited when the rights of another State are at stake. The cases have both focussed on the balancing act to be conducted by the utilising State. Cheng calls this the "interdependence" of rights: "every right is subject to such limitations as are necessary to render it compatible both with a party's contractual obligations and with his obligations under the general law". ${ }^{73}$ If the utilising State uses its resources in a way that is suited to deprive the neighbouring State of its own right, an abuse of right by the utilising State may occur. However, an abuse of rights would require some element of positive bad faith, e.g. when the damage caused by the utilising State is greater than its own gain. ${ }^{74}$ It is submitted, therefore, that there is a duty based on good faith, but under the threshold of abuse of rights, to the extent that a State may only use an absolute right in a way that does not cause damage to another. Both judgments also dealt extensively with the duty to negotiate the effects of the industrial production, an aspect of good faith that will be examined below. ${ }^{75}$

\section{iii. Criticisms by Schwarzenberger/Brown and Lowe}

The broadness of the definition and the difficulty in applying abuse of right has brought it substantial criticism as a general principle. ${ }^{76}$ Schwarzenberger and Brown have stated that it is difficult to establish what constitutes an abuse of rights as opposed to a harsh, yet justified use of a right. ${ }^{77}$ The determination is necessarily one that is subjective, along with being case-dependent, so that there is no place for the concept as a general

\footnotetext{
${ }^{72}$ Case concerning Pulp Mills on the River Uruguay (Argentina v Uruguay) (Merits) [2010] ICJ Rep 18, para 14; Paula Maria Vernet, 'Pulp Mills on the River Uruguay' in MPEPIL (July 2010, online edn) para $7 \mathrm{f}$, available at www.mpepil.com.

${ }^{73}$ Cheng (n 5) 130.

${ }^{74}$ Kiss (n 56) para 4.

${ }^{75}$ See also: Cameron Hutchison, 'Coming in from the Shadow of the Law: The Use of Law by States to Negotiate International Environmental Disputes in Good Faith (2005)

43 Can Ybk Intl L 101, 105 ff.

${ }^{76}$ Neuhaus (n 60) 180.

${ }^{77}$ Schwarzenberger and Brown (n 5) 84.
} 
principle of law. ${ }^{78}$ However, they go on to state that good faith has its place in treaty relations between States. ${ }^{79}$ On the other hand, Lowe states that concepts like abuse of rights are interstitial rights; as such they do not have an independent normative function, but are to be seen as concomitant with the obligations that they underpin. ${ }^{80}$ Even if abuse of right is not in itself a general principle, it can act as a yardstick for the extent of rights and obligations, especially in relation to other States that may be affected as a result. Finally, the modern jurisprudence of the ICJ suggests that the Court will be slow to assume an abuse of rights, unless the evidence is explicitly clear, and that it will favour the interpretation of the parties' acts or agreements, in order to determine the scope of the right or obligation, before reaching such a conclusion. ${ }^{81}$

Abuse of rights still remains relatively loosely defined and needs to be "pruned of its exuberances", ${ }^{82}$ if it is to become a specific rule of customary international law. A lack of consistent State practice means it is not likely a rule of customary international law. However, it can be helpful in determining the use and scope of rights in situations of interdependence. The doctrinal groundwork, particularly in relation to the uses of abuse of rights in municipal law, can work to shed some light on how to approach this conflict between States in international law.

\section{Estoppel and acquiescence}

Further aspects of good faith in international law, which have fairly well established private law counterparts, are the principles of estoppel and acquiescence. A considerable weight of authority supports the view that estoppel is a general principle of international law, resting on principles of good faith and consistency. ${ }^{83}$ Even though private law, particularly the

\footnotetext{
${ }^{78}$ So too, Neuhaus (n 60) 183.

79 Schwarzenberger and Brown (n 5) 118.

${ }^{80}$ Vaughan Lowe, 'The Politics of Law-Making: Are the Method and Character of Norm Creation Changing' in Michael Byers (ed) The Role of Law in International Politics: Essays in international Relations and international Law (OUP 2000) 207, 212221.

${ }^{81}$ Case concerning Military and Paramilitary activities in and against Nicaragua (Nicaragua $v$ United States of America) (Merits) [1986] ICJ Rep 14 para 127; Case concerning the Continental Shelf (Tunisia v Libyan Arab Jamahiriya) (Merits) [1982] ICJ Rep 13 para 42; Thirlway (n 25) 28.

${ }^{82}$ Georg Schwarzenberger, International Law and Order, (Stevens 1971) 88.

${ }^{83}$ Crawford (n 1) 421; IC MacGibbon, 'Estoppel in International Law' (1958) 7 ICLQ 468, 471; ILC, Yearbook of the International Law Commission Vol 2 (1953) A/CN.4/63 (per SR Lauterpacht) 144.
} 
common law, has developed a very multi-faceted approach with variations of estoppel (promissory, equitable, by silence etc.), international law also has its own (albeit more basic) conception. Under the principle of estoppel, a party is not permitted to take up a legal position that is in contradiction with its own previous representations or conduct, when another party has been led to assume obligations towards, or attribute rights to the former party in reliance upon such representations or conduct. ${ }^{84}$

Even though municipal law, particularly contract law, has many different formulations of this behaviour (such as the notion of venire contra factum proprium ${ }^{85}$ ), in international law the remit is broader. ${ }^{86}$ The legitimate reliance of one State (State A) on the conduct of another (State B) precludes this State from acting contrary to its representations. If State B then acts contrary to this representation, it is acting without good faith and therefore in contravention of international law. The principle helps to safeguard a State's legitimate reliance on the actions of other States, in the sense that faith and confidence are protected when they are placed reasonably on the actions of another. This constitutes one of the most important aspects of good faith. ${ }^{87}$

A related, yet distinguishable, aspect is acquiescence, which can be described as the inaction of a State, which is faced with a situation constituting a threat to, or infringement of, its rights. ${ }^{88}$ The two defining differences between estoppel and acquiescence are the components of time and reliance: estoppel hinges on previous presentations; while acquiescence is that passivity in relation to a right of another State to the extent that good

\footnotetext{
${ }^{84}$ ILC, Yearbook of the International Law Commission Vol 2 (1963).

A/CN.4/SER.A/1963/ADD.1 (per SR Waldock) 40; cf for the aspect of reliance:

Thomas M Franck, 'Fairness in the International Legal and Institutional System' (1993) 240 Receuil des Cour 66; MacGibbon (n 83) 468; Litvinoff (n 8) 1664. It is in this regard very similar in nature to the Roman law principle of "non licet venire contra factum proprium" and "allegans contraria non audiendus est"(cf Thomas Cottier and Jörg Paul Müller, 'Estoppel' in MPEPIL (April 2007, online edn) para 9, available at www.mpepil.com.

${ }^{85} \mathrm{Cf} 0$.

${ }^{86}$ Case concerning the Temple of Preah Vihear (Cambodia v Thailand) (Merits) [1962]

ICJ Rep 39 f, (Sep Op Alfaro).

${ }^{87}$ Cheng (n 5) 144; DW Bowett, 'Estoppel before International Tribunals and its Relation to Acquiescence' (1957) 33 British Ybk Intl L 176, $193 \mathrm{f}$.

${ }^{88}$ IC MacGibbon, 'The Scope of Acquiescence in International Law' (1954) 31 British Ybk Intl L 143; in German this would be called "beredtes (oder qualifiziertes)

Schweigen" cf BGH NJW 1951, 711; Jan Busche '§ 147 BGB' in Franz Jürgen Säcker, Roland Rixecker and Hartmut Oetker (eds), Münchener Kommentar zum Bürgerlichen Gesetzbuch, (5th edn, CH Beck 2010 ) para 7.
} 
faith affords the passivity the character of consent. ${ }^{89}$ In the Gulf of Maine Case the ICJ acknowledged the legal effect of a "qualified silence" when it stated that it is "equivalent to tacit recognition manifested by unilateral conduct which the other party may interpret as consent". ${ }^{90}$

One of the inherent difficulties of acquiescence is the establishment of the true intent of the silent state, which is inevitably a legal fiction. ${ }^{91}$ Showing that a State meant to say something (subjective aspect), while remaining silent (objective aspect) has considerable procedural difficulties. The fiction that a State has indeed acquiesced to an infringement of its rights can only be justified if due regard is had to the reasonable trust that the other State had in the subjective value of the silence. ${ }^{92}$

The concepts of estoppel and acquiescence have featured strongly in border and land title disputes. ${ }^{93}$ In this context, the ground-breaking decision was the Temple of Preah Vihear Case. The Temple is an archaeologically and artistically important sanctuary, situated on the Dangrek Mountains between Cambodia and Thailand. In 1904 a Treaty had been signed by France (on behalf of its protectorate, present day Cambodia) with Siam (now Thailand). This called for the delimitation of the area to be performed by a mixed Commission, which produced its maps in 1907 and posited the Temple in Cambodian territory. However, Thailand took the view that it possessed the area surrounding the Temple and took control of the site. Cambodia's diplomatic efforts to regain the territory failed and the case was referred to the ICJ.

The Court relied on acquiescence and estoppel, ${ }^{94}$ rather than looking to the cultural, historic, or religious factors, the ICJ deemed that Thailand should have objected to the maps in a timely manner. Thailand entered no

${ }^{89}$ Jörg Paul Müller, Vertrauensschutz im Völkerrecht, (Carl Heymanns 1971) 38 f; cf MacGibbon (n 88) 143 f; Nuno Sergio Marques Antunes, 'Acquiescence' in MPEPIL (September 2006, online edn) para 19, available at www.mpepil.com; cf Franck (n 84) 68.

${ }^{90}$ Case concerning the Delimitation of the Maritime Boundary in the Gulf of Maine Area (Canada v United States of America) (Merits) [1984] ICJ Rep 305.

${ }^{91}$ Sophie Kopela, 'The Legal Value of Silence as State Conduct in the Jurisprudence of International Tribunals' (2010) 29 Aust Ybk Intl L 101.

${ }^{92}$ A related aspect to acquiescence is that of extinctive prescription; here, a party can lose its rights by not pursuing them in a timely manner. However, a finding of good faith is not strictly necessary and it functions mainly as a procedural right; cf: Müller (n 89) 75; Jennings and Watts (n 39) 705 f; BE King, 'Prescription in Claims in International Law' (1934) 15 British Ybk Intl L 82, 94; Jan Wouters and Sten Verhoeven, 'Prescription' in MPEPIL (November 2008, online edn) para 8, available at www.mpepil.com.

${ }^{93}$ Müller (n 89) $39 \mathrm{f}$.

${ }^{94}$ Case concerning the Temple of Preah Vihear (n 86) $27 \mathrm{f}$. 
reservations to the original Treaty disputing the accuracy of the Commission's maps. Further Friendship Treaty negotiations (in 1925 and 1937) and a Franco-Siamese reconciliation Committee (set up in 1947) also ended with agreements being signed, yet with no reservations entered in respect of the original maps. Coupled with the objective of creating stability and finality ${ }^{95}$ through the demarcation of borders, a legitimate reliance by Cambodia was implied. ${ }^{96}$ Thailand was therefore estopped from raising any objections to the original 1907 maps at the present time, having not made declarations to that effect before. The primary foundation of the principle of estoppel is, as Judge Alfaro noted, "the good faith that must prevail in international relations, inasmuch as consistency of conduct or opinion on the part of the State to the prejudice of another is incompatible with good faith." 97

Acquiescence and estoppel ascribe substantial legal consequences to the inactivity of a State; as such, these institutions should be restrictively interpreted and applied. They find their justification in the reasonable reliance of one State (based on good faith) on the representation or conduct of another. ${ }^{98}$ A State has the ability to make declarations to preserve its rights and preclude the effects of tacit consent, ${ }^{99}$ placing the onus of action on the State that has allowed the reliance and trust.

\section{Negotiations in good faith}

When States negotiate it is not enough for representatives to meet and discuss. Good faith negotiations require the parties to demonstrate 'reasonable regard' for the other's rights and interests. Further, the parties must, with a view to end the dispute amicably, aim for a clear result; in short: the negotiations must be meaningful. ${ }^{100}$ Unjustifiably breaking off the negotiations, creating abnormal delays, disregarding the agreed procedures, or systematic refusal to take into consideration adverse proposals or interests can amount to breaches of good faith. ${ }^{101}$ Even when

\footnotetext{
${ }^{95}$ Cf MacGibbon (n 83) $468 \mathrm{f}$.

${ }^{96}$ Case concerning the Temple of Preah Vihear (n 86) 34; see for the aspect of reliance of the conduct, Nuclear Tests Case (n 2) para 46.

${ }^{97}$ Case concerning the Temple of Preah Vihear (n 86) 42 (Sep Op Alfaro).

${ }^{98}$ Marques Antunes (n 89) para 24; MacGibbon (n 83) 507.

${ }^{99}$ See generally on the standards for these actions or 'pleas', MacGibbon (n 88) $172 \mathrm{ff}$.

${ }^{100}$ O'Connor (n 5) 95, 96; Shaw (n 1) 1017.

${ }^{101}$ Lac Lanoux Arbitration (France v Spain) (Award) [1957] XII RIAA 281; also John

G Laylin and Rinaldo L Binachi, 'The Role of Adjudication in International River

Disputes: The Lac Lanoux Case' (1959) 53 AJIL 30.
} 
there is only a small chance that the negotiations will end in success, the parties are bound by a duty to endeavour to end the dispute. ${ }^{102}$ However, there appears to be no general rule of international law requiring the negotiations to be exhausted before a judicial settlement may be sought. ${ }^{103}$ So far, the ICJ has only developed the obligation to negotiate in good faith in relation to legal rights and has not expanded the notion to any acts between States that do not relate to a legal obligation. ${ }^{104}$

In 1971 Iceland unilaterally announced that it was extending its exclusive fishing zone to 50 nautical miles, thereby terminating agreements it had with Germany and the UK. A dispute ensued before the ICJ. On the merits the Court stressed the need to reconcile the disputed fishing rights through negotiations. The Court also issued the parties with the objectives, which the negotiations should cover, e.g. delimiting the fishing rights, catch-limitations, share allocation and restrictions and required that they should be conducted in good faith. ${ }^{105}$ This judgment builds on the obligation for the negotiations to be 'meaningful', as the Court had noted in an earlier case. ${ }^{106}$

\section{THE INTERRELATION OF GOOD FAITH WITH SOVEREIGNTY}

Historically the principle of internal sovereignty has been understood as the supreme authority, or ultimate power, of a State within its territory, ${ }^{107}$ while the external sovereignty is the dimension that pertains to the international rights and duties of a State in relation to other States. ${ }^{108}$ In 1927, the Permanent Court of International Justice (PCIJ) developed the Lotus

\footnotetext{
102 JG Merrills, International Dispute Settlement, (5 ${ }^{\text {th }}$ edn, CUP 2011) 12.

103 John Collier and Vaughan Lowe, Settlement of Disputes in International Law, (OUP 1999) 21.

104 Judge Padilla Nervo called it an obligation tracto continuo: never ends and is potentially present in all relations and dealings between States, North Sea Continental Shelf Cases (Germany v Denmark/ Netherlands) (Merits) [1969] ICJ Rep 3, para 92 (Sep Op Padilla Nervo).

${ }^{105}$ Fisheries Jurisdiction Case (United Kingdom v Iceland) (Merits) [1974] ICJ Rep 3, $73 \mathrm{f}$.

${ }^{106}$ North Sea Continental Shelf Cases (n 104) para 87.

${ }^{107}$ Customs Regime between Germany and Austria (Advisory Opinion) [1931] PCIJ Rep Series A/B 57 (Ind Op Anzilotti); Samantha Besson, 'Sovereignty' in MPEPIL (April 2011, online edn) para 1, available at www.mpepil.com; Lowe (n 51) 172.

${ }^{108}$ The Island of Palmas case (United States of America $v$ Netherlands) (Award) [1928] II RIAA 838 f (Op. Huber); Besson (n 107) para 70; Ronald Brand, 'Sovereignty: The State, the Individual, and the International Legal System in the Twenty First Century' (2001) 25 Hastings Intl \& Comp L Rev 279, 284.
} 
principle: ${ }^{109}$ based on its sovereignty, a State is free to act ${ }^{110}$ as long as this behaviour is not prohibited by an explicit rule of international law. ${ }^{111}$ Whether this sovereignty is understood as limited or absolute, there is consensus that States must consent to rules that limit them in exercising their sovereignty. ${ }^{112}$

However, applying good faith elements to a State's conduct has a limiting effect on its external sovereignty. The requirement of acting in good faith limits the actions of a State, without the requirement of an explicit rule in international law, as envisaged by the Lotus principle. Accordingly, a state might have its supreme authority or sovereignty limited when aspects of good faith come into play, and these aspects necessitate behaviour that contravenes what a state might otherwise want to do. ${ }^{113}$ The principle of good faith therefore acts not as a source of rights or obligations, but more as a means of guiding the exercise of those rights or obligations. Instead of answering what the obligations placed on a State are, or why they create legal effects for the State, the principle of good faith (and the specific concretisations of that principle discussed above) can guide a State's behaviour as to how the inherent rights and obligations are exercised. This must be considered a limitation on the State's sovereignty. ${ }^{114}$

Regarding the adherence to treaty relations, the limitation of sovereignty is less controversial, as the binding nature of the treaty has been the subject to consent by the State. The Permanent Court of Arbitration (PCA) has, on this point, gone on to state that:

"According to the principle of international law that treaty obligations are to be executed in perfect good faith, therefore excluding the right to legislate at will concerning the subject matter of the treaty, and limiting the exercise of sovereignty of the State bound by a treaty with respect to that subject matter to

\footnotetext{
${ }^{109}$ The Case of the SS Lotus (France v Turkey) (Judgment) [1927] PCIJ Ser A No 104.

${ }^{110}$ The question in the case was of prescribing jurisdiction, as an expression of sovereignty.

${ }^{111}$ Case of the SS Lotus (n 109) 25 f; Armin v Bogdandy and Markus Rau, 'The Lotus' in MPEPIL (June 2006, online edn) paras 9-10, available at www.mpepil.com.

${ }^{112}$ Cf American Law Institute, Restatement of the Law Third, Foreign Relations Law of the United States (St. Paul, 1987) 17 introductory note.

113 Jennings and Watts (n 39) 407 f; Taylor (n 57) 323 f; cf Neuhaus (n 60) 93.

${ }^{114}$ Lukashuk, (n 47) 513, 514, who makes the point that the assumption of obligations can be seen to limit sovereignty, even though undertaking is a realisation of sovereignty; in terms of good faith, the limits placed on the exercise can only be seen to limit a State's actions, absent an express rule in international law.
} 
such acts as are consistent with the treaty."115

\section{Good Faith in the LAW of Treaties}

All signatory States of the Vienna Convention on the Law of Treaties (VCLT) note "that the principles of free consent and of good faith and the pacta sunt servanda rule are universally recognised". ${ }^{116}$ The VCLT is imbued with rules based on good faith that have effect at different stages of the process.

\section{Treaty formation and the element of good faith in Art. 18 VCLT}

After signing (but before ratifying) a treaty, a party has an obligation to observe the terms of the treaty. If a measure is taken after signature that breaches this obligation, one that is based on good faith, reciprocity can allow the other treaty party to repudiate the treaty or to claim compensation for any diminution of value. ${ }^{117}$ The element of good faith in treaty formation is found in Art. $18 \mathrm{VCLT}$. This article protects the legitimate expectations of the other participants in the treaty-making process, and is therefore based on good faith. ${ }^{118}$ Whether or not the signatory State ratifies the treaty is a matter of discretion; however, the consent-based act of placing a signature on the treaty may act to reduce this discretion, so that a State may not exploit the signed text for its own purposes by abusing its inherent discretion to ratify. ${ }^{119}$ It is submitted, though, that there does not exist enough state practice to point to a rule that signature of a treaty leads to a good faith obligation to ratify, but only an obligation not to defeat the purpose or material normative content of the treaty in question. ${ }^{120}$

Even though there is some disagreement as to whether Art. 18 VCLT

\footnotetext{
${ }^{115}$ The North Atlantic Coast Fisheries Case (Great Britain v United States of America) (Award) [1910] XI RIAA 169, para 188.

${ }^{116}$ Third recital.

${ }^{117}$ Arnold McNair, The Law of Treaties, (OUP 1961) 204; Schwarzenberger/ Brown (n 5) $433 \mathrm{f}$.

${ }^{118}$ Oliver Dörr in Oliver Dörr and Kirsten Schmalenbach (eds) Vienna Convention on the Law of Treaties. A Commentary (Springer 2012), Art 18 para 2; Werner Morvay, 'The Obligation of a State not to Frustrate the Object of a Treaty prior to its Entry into Force' (1967) 27 Zeitschrift für ausländisches öffentliches Recht und Völkerrecht 451, 454.

119 JM Jones, Full Powers and Ratification: A study of the development of treaty-making procedure, (CUP 1946) 89; Hassan (n 54) 462.

${ }^{120}$ Hassan (n 54) 461 would seemingly agree; Anthony Aust, Modern Treaty Law and Practice, (2 ${ }^{\text {nd }}$ edn, CUP 2011) 117, suggests the contrary.
} 
reflects customary international law, ${ }^{121}$ international courts and tribunals have taken cognisance of this rule (even prior to the VCLT coming into force). The PCIJ laid the foundation in its judgment on Certain German Interests in Upper Silesia. ${ }^{122}$ The case concerned the alleged breach of good faith by Germany not to alienate certain property in Silesia (as part of the Versailles Treaty), prior to its entry into force. It was held that, even though the facts of the case at hand differed, Germany may not act against the principle of good faith. A misuse of its rights to alienate its property could amount to a breach of its treaty obligation. ${ }^{123}$ The Greco-Turkish arbitral Tribunal was even more explicit in invoking good faith as a foundation not to defeat the object and purpose of a nascent treaty:

“WITH THE SIGNATURE OF A TREATY AND BEFORE ITS ENTRY INTO FORCE, THERE [...] EXISTS AN OBLIGATION TO DO NOTHING WHICH MAY INJURE THE TREATY BY REDUCING THE IMPORTANCE OF ITS OBLIGATIONS [...] THIS PRINCIPLE IS ONLY AN EXPRESSION OF GOOD FAITH.[... ] $]^{\text {'24 }}$

In modern practice, this was affirmed by the Court of Justice of the European Union (CJEU) in Opel Austria v European Council. ${ }^{125}$ The Court, after affirming that good faith forms part of EU law, formulated that the specifically European legal principle of 'legitimate expectations' is a corollary of this general principle. ${ }^{126}$ This further shows that good faith has also taken on a regional customary international law standing (at least as part of EU law). ${ }^{127}$

\section{Performing treaty obligations in good faith (Art. 26 VCLT)}

Art. 26 VCLT, in all its brevity, still makes good faith in the performance of a treaty obligation of paramount importance. Two elements make up this

${ }^{121}$ Laurence Boisson de Chazournes, Anne-Marie La Rosa and Makane Moïse Mbengue in Olivier Corten and Pierre Klein (eds) The Vienna Convention on the Law of Treaties: A Commentary (OUP 2011), Art 18 para 5; Oliver Dörr (n 118) Art 18 para 5; Morvay (n 118) 458 albeit reluctantly states that it conforms to general international law.

${ }^{122}$ Certain German Interests in Polish Upper Silesia (n 64) 5-83.

${ }^{123}$ Cf Hassan (n 54) 454; Cheng (n 5) 110; Anthony Aust differs: cf Aust (n 46) para. 8; Aust (n 120) 117: the act of ratification is the definitive act to create legal consequences, while signature itself does not.

${ }^{124}$ Megalidis $v$ Turkey 8 TAM 395 (cited in Cheng (n 5) 111).

${ }^{125}$ Case T-115/94 Opel Austria GmbH v Council of the European Union [1997] ECR II43.

${ }^{126}$ Ibid para 93; Oliver Dörr in Dörr and Schmalenbach (n 118) Art 18 para 5.

${ }^{127}$ Jan Wouters and Dries Van Eeckhoutte, 'Giving Effect to Customary International

Law through EC Law' KU Leuven Faculty of Law Working Paper 25/2002, 27 ,

available at http://www.law.kuleuven.be/iir/nl/onderzoek/wp/WP25e.pdf. 
obligation: the determination of the object (i.e. the treaty) to be performed in good faith, as well as the manner in which the obligation is performed. ${ }^{128}$

The material duty to act in good faith during the performance of a treaty was stated by Waldock in the ILC's Report as "one of good faith and not stricti juris". ${ }^{129}$ This suggests that the object and intention of the parties is paramount, rather than a literal observation of the wording of the treaty. ${ }^{130}$ A treaty should be performed with the intentions of the parties in mind, rather than looking to a formalistic understanding of the wording. Since the element of good faith is again context-dependent, the duty needs to be applied to the specific details of a case. ${ }^{131}$ It is submitted that elements of the general principles of law that relate to abuse of right, estoppel, and other aspects of good faith may find an analogous application to the performance of treaty obligations.

\section{Good faith in treaty interpretation}

Art. 31 VCLT states that "[a] treaty shall be interpreted in good faith in accordance with the ordinary meaning". Given that the obligation in Art. 26 VCLT applies to the entire process, the interpretation of the treaty is no different. The exact contours of how to interpret a treaty in good faith are difficult, yet an element of 'reasonableness' must be inherent when an interpretation is advanced. ${ }^{132}$ Two aspects that can add contour when interpreting a treaty reasonably are the effectiveness of the interpretation (as an extension), and the imposition of new obligations (as a limitation). Both of these have a basis in good faith.

As a means of interpretation, effet utile helps extend the meaning of the wording past its literal sense, as recourse has to be taken to "what the parties did mean when they used these words". ${ }^{133}$ The principle was left out of the VCLT, as it was feared that it would open the door to a strong

\footnotetext{
128 Jean Salmon in Corten and Klein (n 121) Art 26 para 36.

129 ILC, 'Yearbook of the International Law Commission Vol. II (1964) A/CN.4/SER.A/1964/ADD.1 7.

${ }^{130}$ So too the ICJ: Case concerning the Gabčikovo-Nagymaros Project (Hungary $v$ Slovakia) (Merits) [1997] ICJ Rep 7, para 142.

${ }^{131}$ Cf Jean Salmon in Corten and Klein (n 121) Art 26 para 53.

${ }^{132}$ Cf Oliver Dörr in Dörr and Schmalenbach (n 118) Art 31 para 61; Jean-Marc Sorel and Valerie Bore-Eveno in Corten and Klein (n 121) Art 31 para 29; Richard K Gardiner, Treaty Interpretation, (OUP reprint 2011) 152 f; Jennings and Watts (n 39) 1272 in fn 7.

${ }^{133}$ Case concerning the Arbitral Award of 31 July 1989 (Guinea-Bissau v Senegal)

(Merits) [1991] ICJ Rep 69 f, citing the Admissions Advisory Opinion (n 65) 8;

Gardiner (n 132) 159 f.
} 
teleological interpretation, ${ }^{134}$ which could lead to unwritten (or implied) powers being read into treaties. However, based on the object and purpose of a treaty and a good faith interpretation of it, the favourable construction of a treaty can be achieved of upholding the treaty rather than destroying it (ut res magis valeat quam pereat). ${ }^{135}$ In most cases this will also align with the expectations of the signatory parties, and is a way of interpreting treaties with recourse to good faith. The ordinary meaning of the treaty and the prohibition of creating additional obligations place a limitation on the interpretation. ${ }^{136}$

The obligation to interpret a treaty according to good faith finds its limitations in the creation of new obligations which are no longer covered either by the wording of the treaty or the intent of the signatories. ${ }^{137}$ The approach indicated by judicial practice aims to clear up ambiguous wording, yet not to act as a gap-filling function in order to create new obligations. ${ }^{138}$ By advancing an interpretation that adds (or creates) obligations for another party, not intended or covered by the wording of the treaty, this party may be acting in bad faith.

Even though an undoubted element of good faith pervades the interpretation of international agreements, the ICJ has not yet interpreted a treaty based solely on good faith. ${ }^{139}$ Therefore, it is submitted that, while the ICJ has an undoubtedly well-crafted canon of interpretation that it can draw on, ${ }^{140}$ the principle of good faith is also of an interstitial nature when it comes to treaty interpretation. In this regard it functions as a principle

\footnotetext{
${ }^{134}$ Jean-Marc Sorel and Valerie Bore-Eveno in Corten and Klein (n 121) Art. 31 para 52. The ICJ did, albeit reluctantly, expressed elements of effet utile in: Interpretation of Peace Treaties with Bulgaria, Hungary and Romania (Advisory Opinion, Second Phase) [1950] ICJ Rep 228 f.

${ }^{135}$ Gardiner (n 132) 160.

${ }^{136}$ Interpretation of Peace Treaties (n 134) 226-230; Oliver Dörr in Dörr and Schmalenbach (n 118) Art 31 para 58; Matthias Herdegen, 'Interpretation in International Law' in MPEPIL (February 2010, online edn) para 30, available at www.mpepil.com.

${ }^{137}$ Gardiner (n 132) para 155; Herdegen (n 136) para 30.

${ }^{138}$ Cf The Venezuelan Preferential Claims Case (Germany, Great Britain, Italy, Venezuela et al) (Award) [1904] IX RIAA 110; Netherlands v France (Award, unofficial transcript) [1976] available at http://www.pcacpa.org/showpage.asp?pag_id=1156, paras 54-79; $R v$ Immigration Officer at Prague Airport ex parte European Roma Rights Centre [2004] 2 AC 1, 19 (HL); Gardiner (n 132) $157 \mathrm{f}$.

${ }^{139} \mathrm{Cf}$ Hugh Thirlway, 'The Law and Procedure of the ICJ 1960-1989: Part Three (1991) 62 British Ybk Intl L 17.

${ }^{140}$ In Art. 31-33 VCLT; cf Thirlway (n 139) 16 f.
} 
lending contours without imposing specific obligations ${ }^{141}$ or creating a specific means of constructing a treaty based on good faith alone.

\section{E. Conclusion}

In conclusion, good faith as a general principle of law is familiar from municipal law, but striking in its differences when assessed in the practice of international law. Having examined the specific aspects of good faith and how international jurisprudence has crafted justiciable concretisations out of a vague notion, one conclusion becomes very clear. Whether in general international law or in the law of treaties, good faith acts a limitation. The limitations that the observation of good faith places on States regulate the performance of rights and obligations in international discourse. As well as the explicit duties of good faith in treaty law, general international law places legal consequences on actions that are predicated on good faith.

Returning to Fitzmaurice's statement: while a rule answers 'what' and a principle answers 'why', the principle of good faith regulates 'how'. ${ }^{142}$ As international law becomes more fragmented and dispersed in 'self-contained' regimes, the role of good faith will extend and create more permutations of this limitation, as, fundamentally, good faith acts to give legal value to the expectations that States have in the actions of other States. Good faith might therefore not be readily definable in abstract terms, it is however indispensable.

\footnotetext{
${ }^{141}$ MK Yasseen, 'L'interprétation des traités d'après la Convention de Vienna sur le droit des traités' (1976) 151 Receuil des Cours 21.

${ }^{142}$ Fitzmaurice (n 6) 7, and part 0.
} 